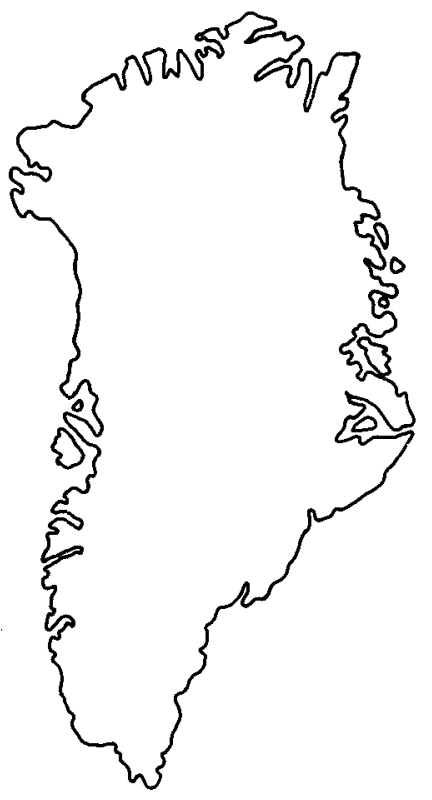

\title{
The age of the Danmarks Fjord Member, eastern North Greenland
}

\author{
M. P. Smith and John S. Peel
}

\begin{abstract}
Conodonts of late Early Ordovician age (late Canadian, earlymiddle Arenigian) are identified from the Danmarks Fjord Member of the Wandel Valley Formation at its type locality near the head of Danmark Fjord, eastern North Greenland. The identifications confirm recent suggestions of an Early Ordovician age for the member made on lithostratigraphic grounds, and refute earlier opinions that the dolomite was probably of Early Cambrian age.
\end{abstract}

M. P. S., Department of Geology, University of Nottingham, Nottingham NG7 2RD, U.K. Present address: Cambridge Arctic Shelf Programme, Department of Earth Sciences, University of Cambridge, Downing St, Cambridge CB2 3EQ, U.K.

J. S. P., Grønlands Geologiske Undersøgelse, Øster Voldgade 10, DK-1350 Kфbenhavn K, Danmark.

The name Danmarks Fjord Dolomite was introduced by Fränkl (1955) for thin sequences of carbonates occurring at Kap Holbæk, near the head of Danmark Fjord (the former Danmarks Fjord), and at Sæfaxi Elv in Kronprins Christian Land (fig. 1). Fränkl's description was apparently based on his own field work in Kronprins Christian Land and on observations made by Adams \& Cowie (1953) at Kap Holbak. The latter authors had previously recognised the dolomite as the un-named basal unit of a thick Ordovician-Silurian carbonate sequence to which they gave the name Centrum Limestone (use of this embracive term has subsequently been abandoned, see Peel et al., 1981).

Recently, Peel et al. (1981) confirmed the practice prevalent in earlier publications (e.g. Cowie, 1961, 1971) and designated Kap Holbak as the type locality for the dolomite.

The Danmarks Fjord Dolomite was originally thought to be of Ordovician age (Adams \& Cowie, 1953; Fränkl, 1955), although subsequent publications by Cowie $(1961,1971)$, Dawes (1976), Christie \& Peel (1977), Poulsen (1978) and O'Connor (1979) have presumed an Early Cambrian age. However, field work in 1979 and 1980 organised by the Geological Survey of Greenland, as part of the 'North Greenland Project 1978-1980', suggested that the Danmarks Fjord Dolomite merely represented the lowest beds of the Wandel Valley Formation of Early-Middle Ordovician age (Peel, 1980; Peel et al., 1981). The Danmarks Fjord Dolomite was therefore no longer considered to be a formation, as was implicit in previous publications, but only a member within the Wandel Valley Formation.

The Danmarks Fjord Member, as the unit is now known (Peel et al., 1981), has not yielded stratigraphically useful macrofossils, but conodonts have been recovered from samples collected in 1980 at Kap Holbæk and from coastal exposures in Kronprins Christian 


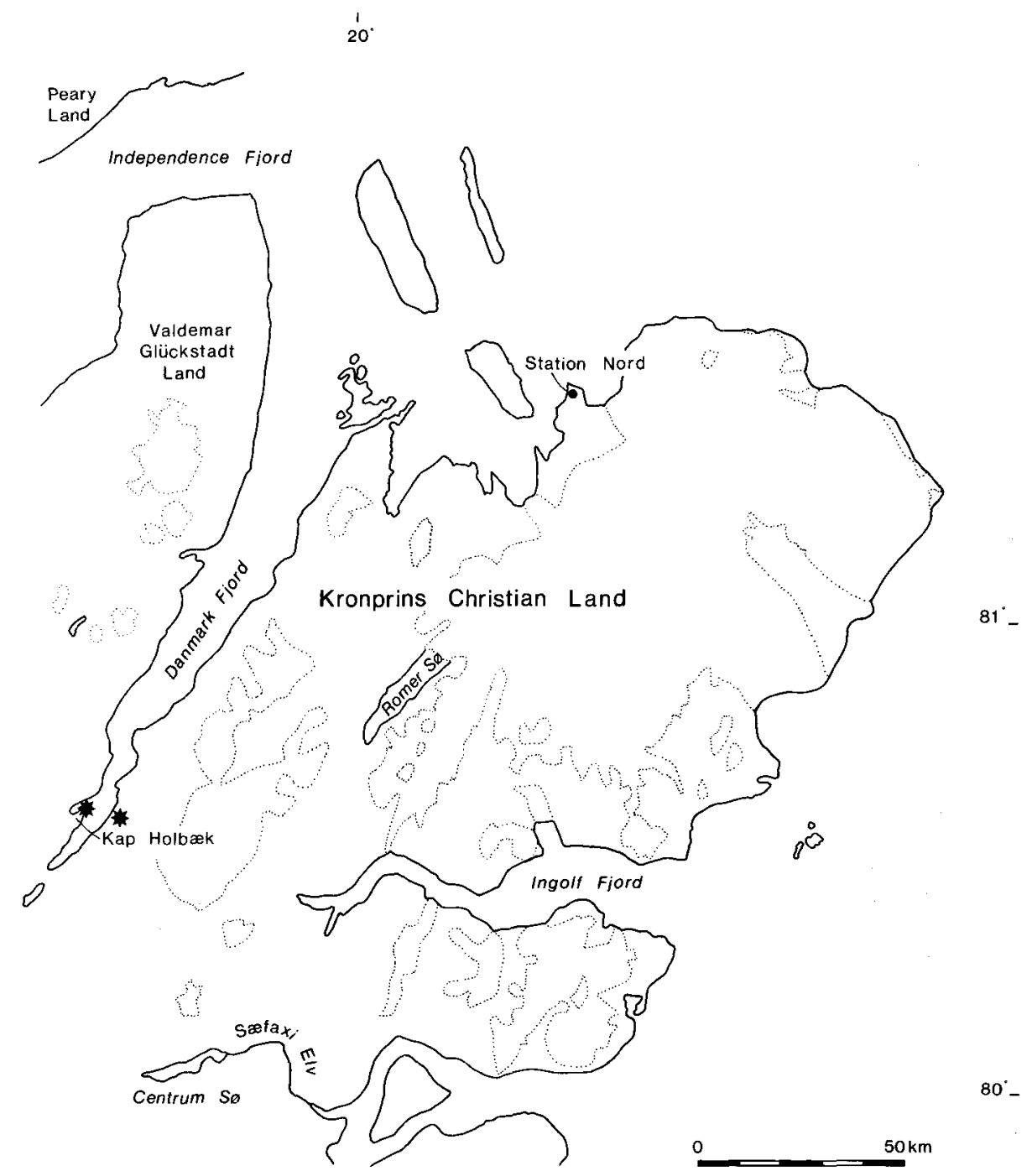

Fig. 1. The Danmark Fjord region of eastern North Greenland. Collection localities are marked with stars. The stippled line indicates the margin of permanent ice caps.

Land, immediately across Danmark Fjord (figs 1,2). The conodonts indicate a late Early Ordovician age (late Canadian, early-middle Arenigian), confirming the recent age reassignment made on lithostratigraphic grounds by Peel et al. (1981).

\section{Danmarks Fjord Member}

This 10-12 m thick basal member of the Wandel Valley Formation has a sharp, erosional contact with the underlying Kap Holbæk Formation. The Kap Holbæk Formation has re- 


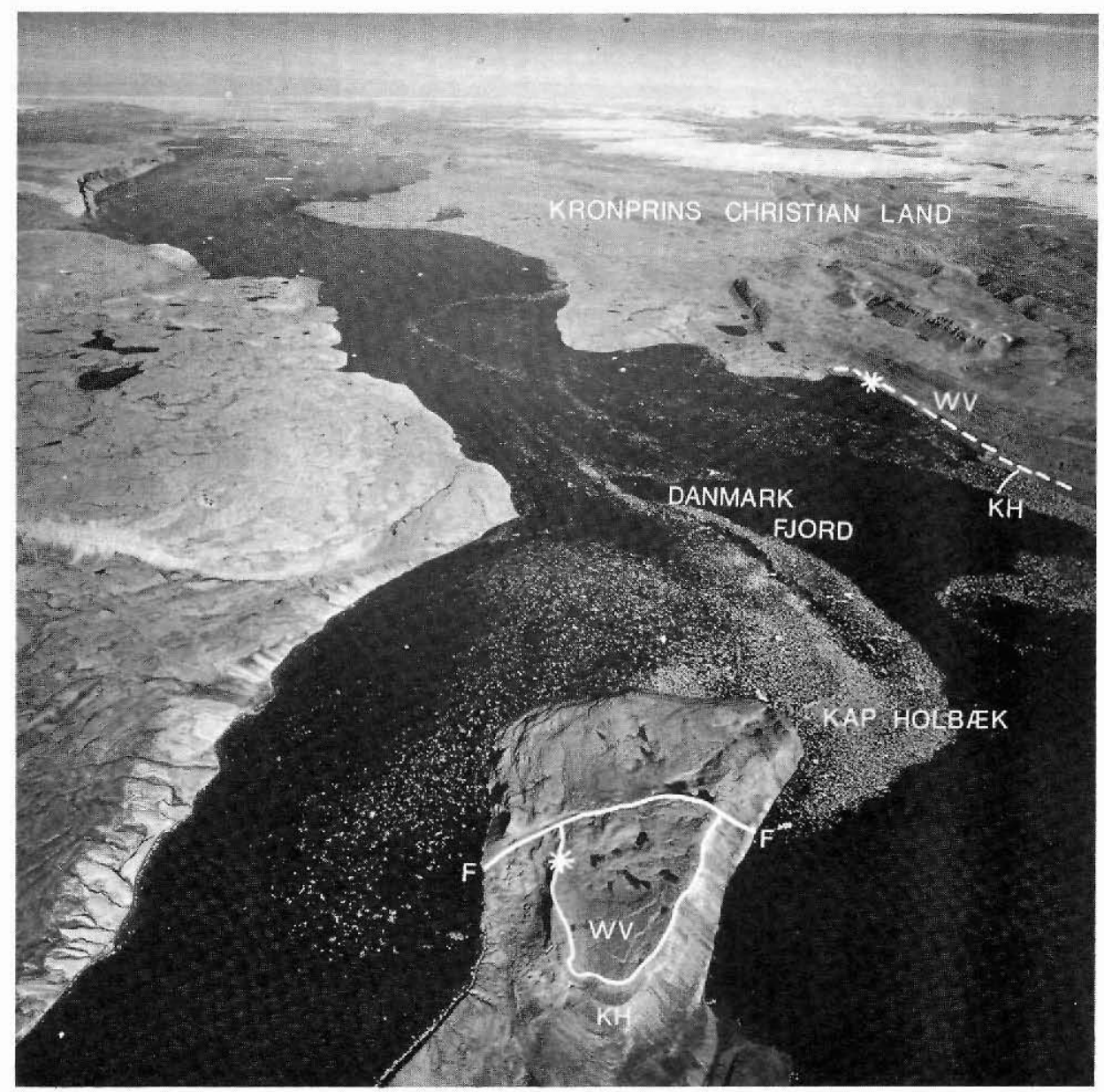

Fig. 2. View from Kap Holbæk (foreground) down Danmark Fjord, looking north-east. Collection localities are indicated by stars. Cliffs south of the prominent east-west fault (FF) on Kap Holbæk are formed by carbonates of the Wandel Valley Formation (WV), overlying the late Proterozoic Kap Holbak Formation (KH). Middle and Upper Ordovician carbonates of the Børglum River Formation form the northern half of the promontory. Cliffs along the coast of Kronprins Christian Land (right of photograph) are composed of the Wandel Valley Formation. The sequence inland of the Wandel Valley Formation consists of Ordovician and Silurian carbonates repeated by thrusting.

cently been correlated with the lithologically very similar Lower Cambrian Buen Formation of Peary Land (Peel, 1982), but study of acritarchs by G. Vicial (Lund) suggests a Proterozoic age (Peel, 1985). The junction is interpreted as a major unconformity (Peel, 1979, 1980; Peel et al., 1981) with the thick, Lower-Upper Cambrian sequences known in Peary Land to the north-west (Ineson \& Peel, 1980) having been overstepped by the transgressive Ordovician Wandel Valley Formation. In general terms, the Danmarks Fjord Member is a brown weathering, grey to dark grey dolomite with undulating laminar or lenticular 
bedding. The laminated horizons often show small, domed stromatolites. Black cherts are common and thin beds of intraformational conglomerate and oolite occur throughout the member.

At Kap Holbæk the Danmarks Fjord Member is very clearly differentiated from the immediately overlying grey weathering limestones of the Amdrup Member of the Wandel Valley Formation, but the junction is transitional in the coastal sections across Danmark Fjord (fig. 1). In Valdemar Glückstadt Land to the north (fig. 1), a thin (5-8 m) prominent pale weathering dolomite with cherts is present between Lower Cambrian clastics of the Buen Formation and dark fossiliferous carbonates of the Wandel Valley Formation. This pale unit, included within the latter formation by Peel (1979, fig. 31), is tentatively correlated with the Danmarks Fjord Member. Christie \& Peel (1977) recognised a tripartite subdivision of the Wandel Valley Formation in its type area in the Børglum Elv region of Peary Land, as is also the case in Kronprins Christian Land (Peel et al., 1981). No correlation is attempted, however, between the three members in each of the respective areas.

Previous discussion concerning the age and correlation of the Danmarks Fjord Member was summarised by Peel et al. (1981). Suggested correlations with the Brønlund Fjord Formation (Cowie, 1961, 1971; Dawes, 1976; Christie \& Peel, 1977), the Portfjeld Formation and the Buen Formation (Poulsen, 1978; O'Connor, 1979; see also Peel, 1979) of Peary Land, all of early Cambrian age, were discounted. The member was referred to the Wandel Valley Formation and concluded to be of late Canadian (late Early Ordovician) age. A similar age assignment is perhaps implicit in the stratigraphic scheme employed by Adams \& Cowie (1953) and it is ironic that despite later general agreement of a Cambrian age, the present conodont age determinations confirm this original supposition. Fränkl (1955) noted the close relationship between the Danmarks Fjord Member and the overlying late Canadian carbonates reported by Adams \& Cowie (1953) and in consequence suggested an early Canadian (early Early Ordovician) age.

\section{Derivation of samples}

Five samples were processed by standard techniques of acetic acid digestion and bromoform density separation in the Micropalaeontology Unit, Department of Geology, Nottingham University.

GGU samples 274929, 274932 and 274933 were collected by J. R. Ineson and J. S. Peel on the western side of the Kap Holbæk peninsula (fig. 1). GGU samples 274914 and 274915 were also collected by Ineson and Peel but in Kronprins Christian Land, in the banks of a stream flowing north-westward into Danmark Fjord (fig. 1).

\section{Conodont faunas}

Preliminary identifications from the four fossiliferous samples are shown in Table 1. Glyptoconus quadraplicatus (Branson $\&$ Mehl, 1933) is by far the dominant species (fig. 3A). The quadricostate and tricostate forms are both present and the transition between the two noted by Kennedy (1980) and Ethington \& Clark (1982) is also evident. The costae and intermediate grooves vary from being very weakly to strongly developed and a few of the specimens resemble the 'gargantuan' morphotype illustrated by Kennedy (1980, Pl. 1, fig. 45). $G$. quadraplicatus ranges from the $G$. quadraplicatus/Scolopodus aff. $S$. rex Interval to the $J u$ - 
Table 1. Conodonts from the Danmarks Fjord Member

\begin{tabular}{|c|c|c|c|c|}
\hline GGU No. & 274929 & 274933 & 274914 & 274915 \\
\hline Eucharodus parallelus (Branson \& Mehl) & 18 & 1 & & 13 \\
\hline Glyptoconus quadraplicatus (Branson \& Mehl) & 21 & & 6 & 41 \\
\hline $\begin{array}{l}\text { Scandodus furnishi Lindström sensu } \\
\text { Ethington \& Clark }\end{array}$ & 2 & & & \\
\hline Ulrichodina abnormalis (Branson \& Mehl) & 2 & & & \\
\hline Drepanodiform elements & 8 & & 2 & \\
\hline Total number of conodonts & 51 & 1 & 8 & 54 \\
\hline
\end{tabular}

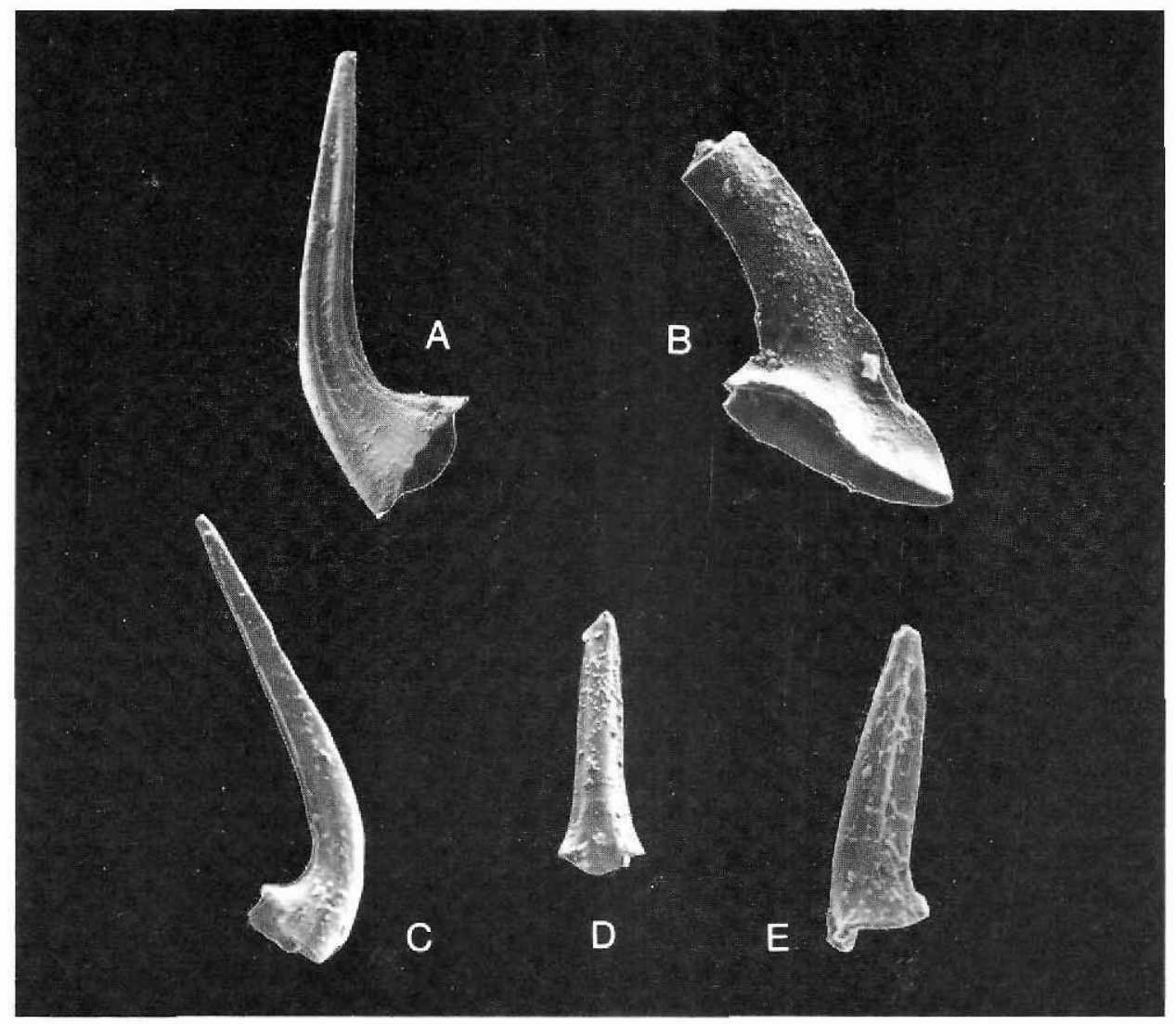

Fig. 3. Lower Ordovician conodonts from the Danmarks Fjord Member. All specimens except Glyptoconus quadraplicatus are from GGU 274929. G. quadraplicatus is from GGU 274915. A. Glyptoconus quadraplicatus (Branson \& Mehl), MGUH 17.099, × 85; B, 'Scandodus' furnishi Lindström sensu Ethington \& Clark, 1964, MGUH 17.100, × 80; C, Eucharodus parallelus (Branson \& Mehl), MGUH $17.101, \times 60 ; \mathrm{D}$, Ulrichodina abnormalis (Branson \& Mehl) anterior view, MGUH 17.102, $\times 80 ; \mathrm{E}, \mathrm{Ul}$ richodina abnormalis (Branson \& Mehl) lateral view, MGUH 17.103, $\times 100$. MGUH refers to the type collection of the Geological Museum, Copenhagen. 
modontus gananda/?Reutterodus andinus Interval in the conodont biostratigraphic scheme of Ethington \& Clark (1982, see fig. 3), erected in the Ibex area of Utah.

Eucharodus parallelus (Branson \& Mehl, 1933) is a highly variable element (fig. 3C) with a stratigraphic range from the Cordylodus intermedius Interval to the Microzarkodina flabellum/Tripodus laevis Interval of Ethington \& Clark (1982). The element cross-section varies from subcircular to lenticular and the degree of recurvature is variable.

Specimens here assigned to Scandodus furnishi Lindström, 1955 sensu Ethington \& Clark (1964) (fig. 3B) bear a close resemblance to those specimens figured as $S$. furnishi and Oistodus sp. aff. forceps by Ethington \& Clark (1964, pl. 113, fig. 19; pl. 114, figs 9, 11, 12). These specimens have subsequently been reasigned to Oistodus inaequalis Pander, 1856 by Ethington \& Clark (1982). O. inaequalis has been included as an element of Drepanoistodus (van Wamel, 1974) and Paltodus (Lindström, 1977) but none of the associated elements of these apparatuses have been recovered from Greenland. It is likely that this element belongs to a new species. For the time being, however, it is considered preferable to retain it under the name of the original description, although the element is not part of the apparatus of $S$. furnishi Lindström. The specimens of Ethington \& Clark (1982) have a range from the Acodus deltatus/Macerodus dianae Interval to the Protoprioniodus aranda/Juanognathus jaanussoni Interval.

The genus Ulrichodina (figs 3D, 3E) is a rare, yet characteristic, component of Early Ordovician Midcontinent Province conodont faunas. The few specimens of Ulrichodina abnormalis (Branson \& Mehl, 1933) recorded by Ethington \& Clark from the Ibex area occurred in samples from the Acodus deltatus/Macerodus dianae Interval to the Jumudontus ganandal ?Reutterodus andinus Interval.

\section{Conclusions}

The conodont faunas recorded from the Danmarks Fjord Member of the Wandel Valley Formation demonstrate conclusively the Early Ordovician age of the unit, previously postulated on lithostratigraphic grounds (Peel, 1980; Peel et al., 1981). Taxa from four samples are indicative of a general late Early Ordovician age.

One sample (GGU 274929) collected from near the base of the member yields species which enable a more precise stratigraphic assignment. The species 'Oistodus' inaequalis and Ulrichodina abnormalis together indicate a stratigraphic range from the Acodus deltatus/ Macerodus dianae Interval to the Protoprioniodus aranda/Juanognathus jaanussoni Interval. This corresponds to a range of $F$ to $K$ in the trilobite zones of Hintze (1951) which were also established in the Ibex area. A late Canadian age (early to middle Arenigian) is inferred.

Conodonts have also been recovered from the lower part of the Wandel Valley Formation in its type area in southern Peary Land, some $150 \mathrm{~km}$ north-west of Kap Holbæk (fig. 1). The faunas there are more diverse, but the lowest samples in the Wandel Valley Formation contain all the species recovered from the Danmarks Fjord Member.

Acknowledgement. Figure 2 is reproduced with permission from the Geodætisk Institut, Copenhagen (A495/79). Dr R. J. Aldridge commented on an early draft of the paper. 


\section{References}

Adams, P. J. \& Cowie, J. W. 1953: A geological reconnaissance of the region around the inner part of Danmarks Fjord, Northeast Greenland. Meddr Grønland 111(7), 24 pp.

Christie, R. L. \& Peel, J. S. 1977: Cambrian-Silurian stratigraphy of Børglum Elv, Peary Land, eastern North Greenland. Rapp. Grønlands geol. Unders. 82, 48 pp.

Cowie, J. W. 1961: The Lower Palaeozoic geology of Greenland. In Raasch, G. O. (edit.) Geology of the Arctic 1, 160-169. Toronto U.P.

Cowie, J. W. 1971: The Cambrian of the North American Arctic regions. In Holland, C. H. (edit.) Cambrian of the New World, 325-383. London: Interscience.

Dawes, P. R. 1976: Precambrian to Tertiary of northern Greenland. In Escher, A. \& Watt, W. S. (edit.) Geology of Greenland, 248-303. Copenhagen: Geol. Surv. Greenland.

Ethington, R. L. \& Clark, D. L. 1964: Conodonts from the El Paso Formation (Ordovician) of Texas and Arizona. J. Paleont. 38, 685-704.

Ethington, R. L. \& Clark, D. L. 1982: Lower and Middle Ordovician conodonts from the Ibex area, Western Millard County, Utah. Brigham Young Univ. Geol. Studies 28, pt. 2, 160 pp.

Fränkl, E. 1955: Weitere Beiträge zur Geologie von Kronprins Christians Land (NE-Grönland). Meddr Grønland 103(7), $35 \mathrm{pp}$.

Hintze, L. F. 1951: Lower Ordovician detailed stratigraphic sections for western Utah. Bull. Utah Geological and Mineralogical Survey 39, 99 pp.

Ineson, J. R. \& Peel, J. S. 1980: Cambrian stratigraphy in Peary Land, eastern North Greenland. Rapp. Grønlands geol. Unders. 99, 33-42.

Kennedy, D. J. 1980: A restudy of conodonts described by Branson and Mehl, 1933, from the Jefferson City Formation, Lower Ordovician, Missouri. Geologica et Palaeontologica 14, 45-76.

Lindström, M. 1977: Paltodus. In Ziegler, W. (edit.) Catalogue of conodonts III. Stuttgart: E. Schweizerbart'sche Verlagsbuchhandlung, $574 \mathrm{pp}$.

O'Connor, B. 1979: The Portfjeld Formation (?early Cambrian) of eastern North Greenland. Rapp. Grønlands geol. Unders. 88, 23-28.

Peel, J. S. 1979: Cambrian - Middle Ordovician stratigraphy of the Adams Gletscher region, south-west Peary Land, North Greenland. Rapp. Gronlands geol. Unders. 88, 29-39.

Peel, J. S. 1980: Geological reconnaissance in the Caledonian Foreland of eastern North Greenland with comments on the Centrum Limestone. Rapp. Gronlands geol. Unders. 99, 61-72.

Peel, J. S. 1982: The Lower Paleozoic of Greenland. In Embry, A. F. \& Balkwill, H. R. (edit.) Arctic geology and geophysics. Mem. Can. Soc. Petrol. Geol. 8, 309-330.

Peel, J. S. 1985: Cambrian-Silurian platform stratigraphy of eastern North Greenland. In Gee, D. G. \& Sturt, B. A. (edit.) The Caledonide Orogen - Scandinavia and related areas, 1077-1094. New York: Wiley \& Sons.

Peel, J. S., Ineson, J. R., Lane, P. D. \& Armstrong, H. A. 1981: Lower Palaeozoic stratigraphy around Danmark Fjord, eastern North Greenland. Rapp. Grønlands geol. Unders. 106, 21-27.

Poulsen, V. 1978: The Precambrian-Cambrian boundary in parts of Scandinavia and Greenland. Geol. Mag. 115, 131-136.

van Wamel, W. A. 1974: Conodont biostratigraphy of the Upper Cambrian and Lower Ordovician of northwestern Öland, southeastern Sweden. Bull. Utrecht Micropaleont. 10, $126 \mathrm{pp}$. 